\title{
Glacier Flow Dynamics of the Severnaya Zemlya Archipelago in Russian High Arctic Using the Differential SAR Interferometry (DInSAR) Technique
}

\author{
Bala Raju Nela ${ }^{1}$, Debmita Bandyopadhyay ${ }^{1}$ (D), Gulab Singh ${ }^{1, *}$, Andrey F. Glazovsky ${ }^{2}{ }^{\circledR}$, \\ Ivan I. Lavrentiev ${ }^{2}$, Tatiana E. Kromova ${ }^{2}$ and Jorge Arigony-Neto ${ }^{3}(\mathbb{D}$ \\ 1 Centrer of Studies in Resources Engineering, IIT Bombay, Mumbai 400076, India; balaraju@iitb.ac.in (B.R.N.); \\ debmitab@iitb.ac.in (D.B.) \\ 2 Institute of Geography, Russian Academy of Sciences, Moscow 119991, Russia; glazovsky@igras.ru (A.F.G.); \\ ilavrentiev@gmail.com (I.I.L.); tkhromova@gmail.com (T.E.K.) \\ 3 Instituto de Oceanografia, Universidade Federal do Rio Grande (FURG), Rio Grande 96203-900, Brazil; \\ jorgearigony@furg.br \\ * Correspondence: gulab.singh@iitb.ac.in
}

Received: 30 September 2019; Accepted: 13 November 2019; Published: 23 November 2019

\begin{abstract}
Glacier velocity is one of the most important parameters to understand glacier dynamics. The Severnaya Zemlya archipelago is host to many glaciers of which four major ice caps encompassing these glaciers are studied, namely, Academy of Sciences, Rusanov, Karpinsky, and University. In this study, we adopted the differential interferometric synthetic aperture radar (DInSAR) method utilizing ALOS-2/PALSAR-2 datasets, with a temporal resolution of 14 days. The observed maximum velocity for one of the marine-terminating glaciers in the Academy of Sciences Ice Cap was $72.24 \mathrm{~cm} /$ day $(\approx 263 \mathrm{~m} / \mathrm{a})$. For the same glacier, an increment of 3.75 times the flow rate was observed in 23 years, compared to a previous study. This has been attributed to deformation in the bed topography of the glacier. Glaciers in other ice caps showed a comparatively lower surface velocity, ranging from 7.43 to $32.12 \mathrm{~cm} /$ day. For estimating the error value in velocity, we selected three ice-free regions and calculated the average value of their observed movement rates by considering the fact that there is zero movement for ice-free areas. The average value observed for the ice-free area was $0.09 \mathrm{~cm} / \mathrm{day}$, and we added this value in our uncertainty analysis. Further, it was observed that marine-terminating glaciers have a higher velocity than land-terminating glaciers. Such important observations were identified in this research, which are expected to facilitate future glacier velocity studies.
\end{abstract}

Keywords: glacier movement; differential SAR interferometry; marine-terminating glacier

\section{Introduction}

Glaciers are a reliable indicator of climate change [1-4], since variations in glacier dynamics, such as glacier velocity, thickness, and mass balance, can directly be related to variations in climate parameters, such as temperature and precipitation. Monitoring glacier dynamics is significantly important in assessing the contribution from glacier melt-water to sea-level rise [5,6], response of ice masses in different regions to climate change, and even for water resource management at local and regional scales. Among the several techniques of estimating glacier ice flow velocities, measurements using the Differential Global Positioning System (DGPS) is the most accurate [7]. However, this technique is time consuming, labor-intensive, and spatially-restricted. Conversely, glacier surface velocity can also be estimated using the satellite based differential interferometric synthetic aperture radar (DInSAR; using synthetic aperture radar (SAR) data) or offset tracking (using optical/SAR data) techniques. Previous researchers have leveraged the use of remotely sensed data onboard space-borne 
satellites to measure glacier velocity [8-11]. However, several advantages of active microwave sensors (like all-weather observing and penetration capability), especially synthetic aperture radar (SAR) over its counterparts like optical data, make them a preferred choice in such studies. DInSAR is a radar interferometry technique used to measure glacier movement [10-14], land subsidence/uplift rate [15,16], earthquake [10,17-19], and volcanic studies [20,21]. The DInSAR technique was first used to map the Landers Earthquake in California [22] and to monitor the Rutford ice stream motion in Antarctica [10]. In this study, the two-pass DInSAR technique was used to estimate the glacier velocity by differencing the phase information of two SAR datasets separated in time. Minute variations (millimeter scale) in the phase are reflected in the estimation of velocity, thus making the technique highly precise. Another technique of velocity estimation is the offset-tracking method [8,23,24]; its accuracy is in the order of one-tenth of the pixel spacing [25]. The major difference between these two techniques is that DInSAR uses phase information to determine the displacement/movement, but offset-tracking uses amplitude/intensity information to identify the pixel offset value(s) in both range and azimuth. Hence, it is less accurate than the DInSAR technique [25,26].

In the Severnaya Zemlya archipelago region, velocity was estimated for different ice caps using these two different remote sensing techniques. Dowdeswell et al. [27] estimated velocity, elevation, and thickness of the Academy of Sciences Ice Cap using ERS Tandem pair, acquired during the ablation season of 1995 with a 1-day temporal gap. They also used the same SAR interferometry technique to estimate the velocity of this ice cap. Sánchez-Gámez et al. [28] also estimated the velocity for the same region, the Academy of Sciences Ice Cap, in the accumulation season of 2017, using Sentinel-1 with a 12-day temporal gap utilizing different SAR datasets using the offset-tracking technique. Michael et al. [29] estimated the Vavilov Ice Cap (one of the ice caps in the Severnaya Zemlya archipelago) surface motion using Landsat-8 optical data in the years of 2013, 2015, and 2016, with the help of offset-tracking technique. The NASA Making Earth Science Data Records for Use in Research Environments (MEaSUREs) Inter-mission Time Series of Land Ice Velocity and Elevation (ITS_LIVE) project [30] provides the velocity maps for this study area, estimated using the pixel tracking technique with the help of Landsat data. The main objective of this study was to estimate the movement of the Severnaya Zemlya archipelago region using the DInSAR technique and to understand the dynamics of this area, as it is more accurate than pixel tracking method. The DInSAR method is highly sensitive to the interferometry pair, which must have high coherence in order to have a reliable estimate of velocity. Hence, we carefully selected an interferometry pair with longer wavelength and less temporal baseline to improve the coherence [31]. Previous studies have estimated flow rates mainly for the Academy of Science Ice Cap using both the DInSAR [27] and offset-tracking [28] techniques. However, the movement for the entire archipelago using DInSAR has not been reported to date. In this work, we present glacier flow velocities for four ice caps (Academy of Sciences, Rusanov, Karpinsky, and University) in the Severnaya Zemlya archipelago using DInSAR, from which we try to understand the variability (small to large) in the flow rates of both land- and marine-terminating glaciers, as well as the physical significance behind an accelerated velocity rate in Academy of Sciences.

\section{Datasets and Study Area}

The selection of interferometry pair images for the DInSAR process, especially for glacier movement, is very important. The Advanced Land Observing Satellite (ALOS-2), also called DAICHI-2, is equipped with the Panchromatic L-band (wavelength $24 \mathrm{~cm}$ ) Synthetic Aperture Radar (PALSAR-2) sensor launched by Japan Aerospace Exploration Agency (JAXA) in 2014, mainly for disaster management and for various applications in cartography, regional observation, and resource surveys. It collects data with three different modes, namely, Spotlight (resolution: 1-3 m), Strip Map (resolution: 3, 6, and $10 \mathrm{~m}$ ), and Scan SAR (resolution: $100 \mathrm{~m}$ ). In addition, L-band SAR data are best suitable for cryospheric studies, because the penetration capacity is higher through clouds and snow-covered regions compared to C-band (Sentinel-1) and X-band (TerraSAR-X) datasets. The two-pass approach was adopted to generate differential interferograms. Eleven pairs of ALOS-2/PALSAR-2 scenes with a 
temporal gap of 14 days acquired over the Severnaya Zemlya archipelago region was used in this study (Table 1). Although the acquisitions were made in dual polarization ( $\mathrm{HH}$ and $\mathrm{HV}$ ), we utilized only $\mathrm{HH}$ polarization for estimating the glacier velocity. Further, the entire area is covered by ALOS-2/PALSAR-2 in two path acquisitions (132 and 134) as shown in Figure 1.

Table 1. Details of selected Single Look Complex (SLC) datasets for the DInSAR process (HH: horizontal polarization transmit and horizontal polarization received by the SAR sensor, HV: horizontal polarization transmit and vertical polarization received by the SAR sensor, $\mathrm{HH}+\mathrm{HV}$ : dual polarimetric SAR data).

\begin{tabular}{ccccc}
\hline Pair No. & Dates & Path Number & Temporal Baseline (days) & Polarization \\
\hline \multirow{2}{*}{1 to 4} & $28 / 03 / 2014$ & 134 & 0 & $\mathrm{HH}+\mathrm{HV}$ \\
& $11 / 04 / 2018$ & 134 & 14 & $\mathrm{HH}+\mathrm{HV}$ \\
5 to 11 & $01 / 04 / 2018$ & 132 & 0 & $\mathrm{HH}+\mathrm{HV}$ \\
& $15 / 04 / 2018$ & 132 & 14 & $\mathrm{HH}+\mathrm{HV}$ \\
\hline
\end{tabular}

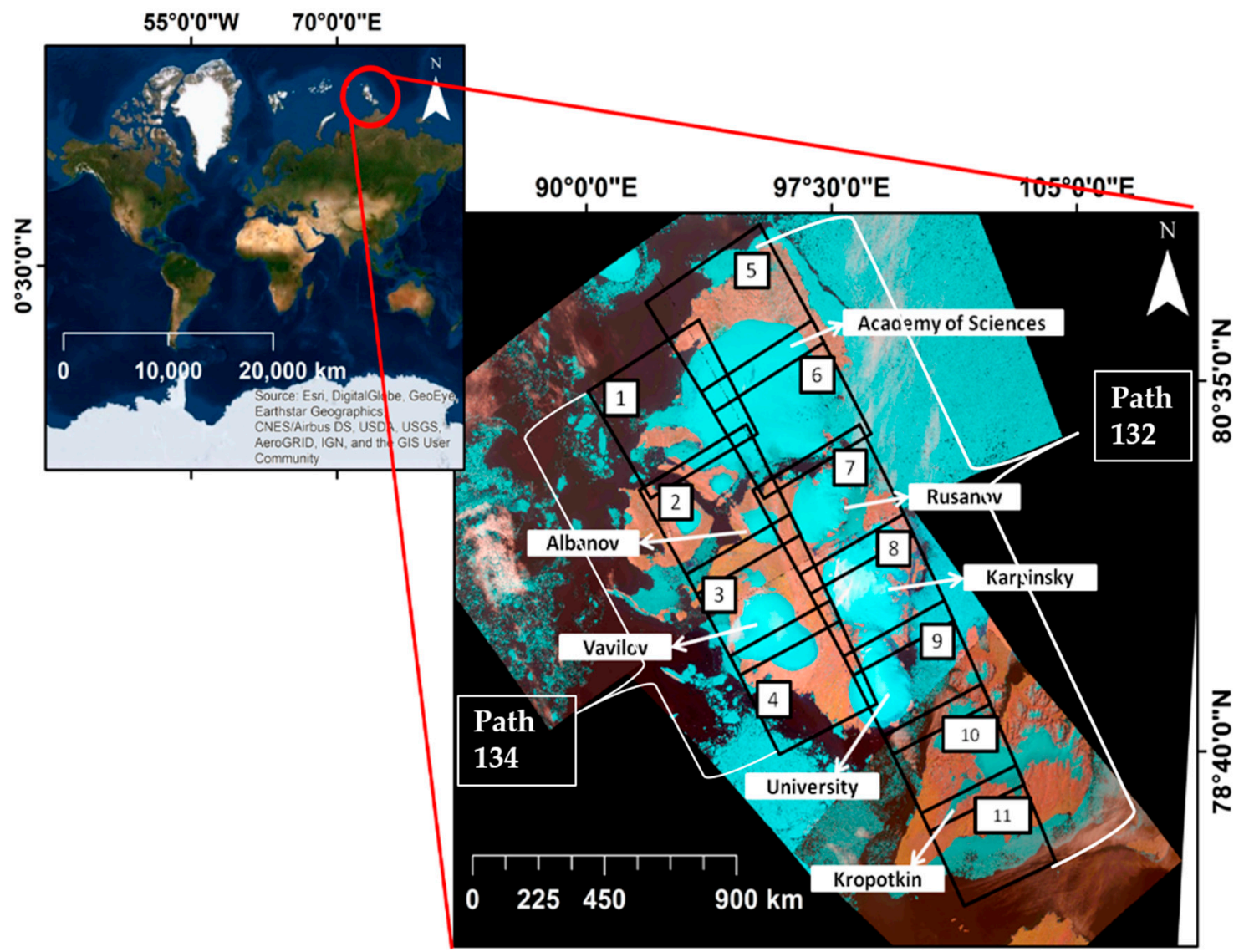

Figure 1. The study area of the Severnaya Zemlya archipelago using Landsat-8 natural color image in the background and black color rectangular box as the ALOS-2/PALSAR-2 coverage scenes marked with numbers from 1 to 11 (from 1 to 11 ).

These L-band SAR pairs were acquired in March and April 2018 with a temporal baseline of 14 days. The external Digital Elevation Model (DEM) utilized in the study was the 1-arc second (resolution: $30 \mathrm{~m}$ ) Advanced Spaceborne Thermal Emission and Reflection Radiometer (ASTER) DEM to remove topographic phase from the interferogram. The DInSAR-generated line of sight (LOS) velocity map was later converted to horizontal flow velocity using the slope map, which was generated using the same ASTER DEM. DInSAR-based velocity results were compared with velocity 
data generated using autonomous Repeat Image Feature Tracking (auto-RIFT) [32], which is freely provided by the NASA MEaSUREs ITS_LIVE project.

Severnaya Zemlya is the easternmost glacierized archipelago in the Russian Arctic and consists of four main islands (Figure 1), with a total area of $36,800 \mathrm{~km}^{2}$, and about $16,400 \mathrm{~km}^{2}$ is ice-covered [31]. In the past few years, the glaciers in Severnaya Zemlya have attracted attention because of the ongoing disintegration of the Matusevich Ice Shelf that started in 2012, and the prominent surge of the western basin of the Vavilov Ice Cap (both are on October Revolution Island) [26,27].

\section{Methodology}

\subsection{Glacier Movement Using DInSAR}

In the DInSAR process, HH polarization of the Single Look Complex (SLC; Level 1.1) data of the ALOS-2/PALSAR-2 pair was used to generate the interferogram. The available SAR images did not cover the entire area of the Severnaya Zemlya archipelago for the selected time period. Hence, we used eleven different interferometry pair images acquired at the end of the 2018 accumulation season. The PALSAR-2 acquisitions on 28 March 2018 (path 134) and 1 April 2018 (path 132) are considered as the master images, while that acquired 14 days later on 11 April 2018 (path 134) and 15 April 2018 (path 132 ) are the respective slave images. Sub-pixel accuracy co-registration was performed on the SLCs using the cross-correlation algorithm. The slave image was shifted using the offset values obtained from co-registration to perfectly match with the master image. The differential phase $(\Delta \varphi=\varphi 1-\varphi 2)$ of the interferogram consisted of the displacement component due to glacier motion, as well as the topographic phase information apart from phase due to atmospheric phase and phase noise. While the phase noise and atmospheric phase are assumed to be non-interfering (based on the coherence) leaving behind phase due to glacier motion and topography. The topographic phase can be eliminated with help of an external DEM, leaving behind only the phase due to the displacement (due to glacier movement) in the differential interferogram. But this differential interferogram phase was wrapped between $-\pi$ and $\pi$. A Minimum Cost Flow (MCF) phase unwrapping technique was used to retrieve the original phase that was finally converted into displacement $(\Delta r)$ using the following equation [22], where $\Delta \phi$ is the differential phase and $\lambda$ is the wavelength of the radar signal:

$$
\Delta r=\frac{\lambda}{4 \pi} \Delta \phi
$$

The DInSAR technique gives the glacier velocity in LOS direction, which can be further used to calculate the horizontal flow velocity $\left(V_{H F}\right)$ using incidence angle and slope of the glacier [10]. Henceforth, the horizontal flow velocity will be referred to as the glacier velocity.

$$
V_{H F}=\frac{V_{L O S}}{\sin \theta \cos \alpha}
$$

where $\theta$ is an inclination angle and $\alpha$ is the slope of the glacier. The overall procedure is summarized in Figure 2. 


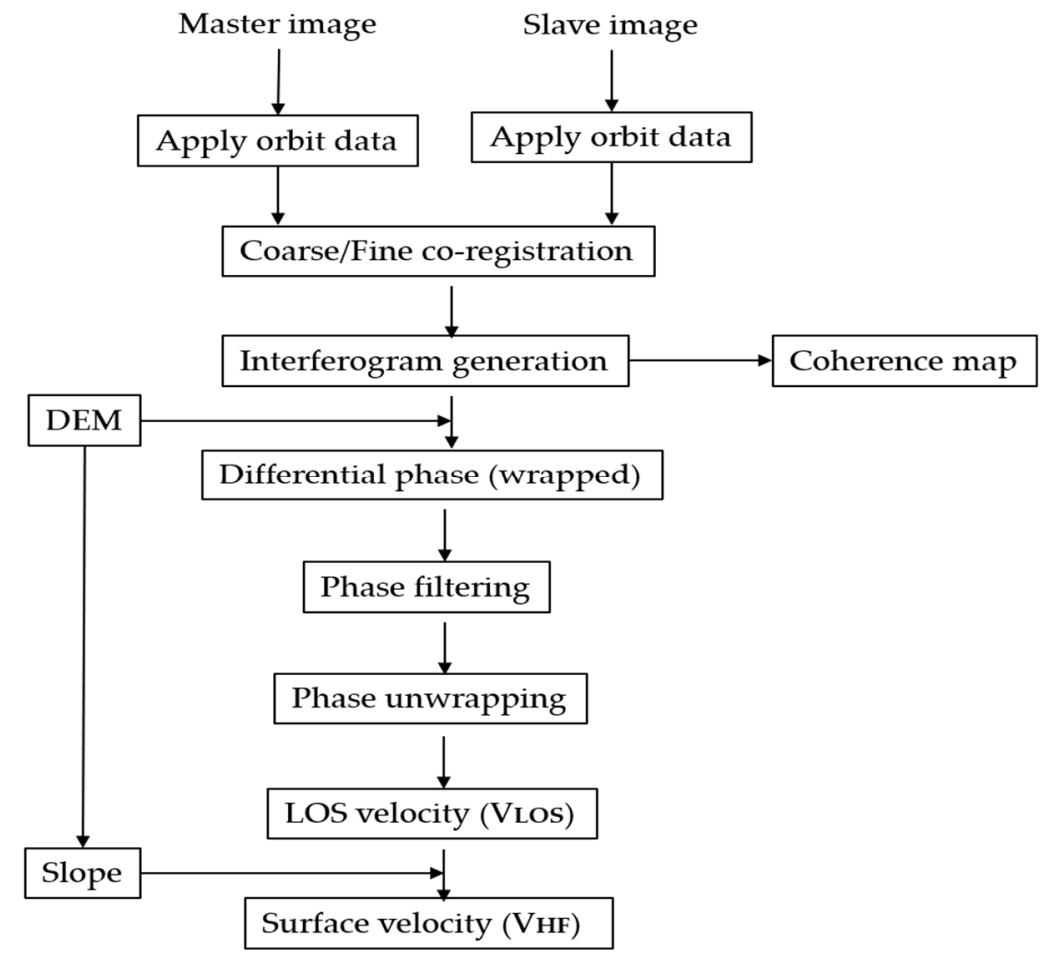

Figure 2. Methodology for the DInSAR technique. DEM, Digital Elevation Model; LOS, line of sight.

\subsection{Error Analysis}

For glacier/ice cap flow, the assessment of decorrelation effects is difficult in the DInSAR process because its velocity varies temporally (in a year) and spatially (along the depth and glacier flowline) [33]. Goldstein et al. [10] reported the accuracies of this technique as $1.5 \mathrm{~mm}$ for vertical motion and $4 \mathrm{~mm}$ for horizontal motion. The error sources in the interferometry process are mainly due to atmosphere, DEM, and phase noise. One of the methods to estimate uncertainty in the DInSAR process is calculating the individual errors due to the sources of DEM, atmosphere and phase noise, etc., and combining all the errors. This approach is computationally intensive. However, in this study, deformation error due to DEM error was estimated (using ASTER DEM to remove the topography component from the interferogram to estimate only displacement component) by considering the standard deviation (SD) value of this DEM as $12.1 \mathrm{~m}$ [34]. We calculated approximate deformation error in LOS direction using the following equation [35].

$$
\partial_{\Delta_{r}}=\frac{B_{\perp}}{R_{1} \sin \theta_{1}} \partial_{h}
$$

where $\partial_{h}$, is the DEM induced error, $B_{\perp}$ is the perpendicular baseline, $R_{1}$ is the slant range distance and $\theta_{1}$ is the look angle. As an alternate approach in this study to estimate uncertainty in the DInSAR-based glacier velocity, we used the observed movement rate for ice-free regions. Ice-free regions should give zero movement, but the value introduced in these regions is due to the combination of all error sources. We calculated the average value of these ice-free regions and considered it as an uncertainty value.

\section{Results}

We observed that amongst all the glaciers in our study area, both in LOS velocity (Figure 3) and in the annual flow velocity (Figure 4), glacier ' $A$ ' in the Academy of Sciences ice cap has the highest magnitude $(\approx 263 \mathrm{~m} / \mathrm{a})$. In-depth analysis shows that this glacier ' $\mathrm{A}$ ' is moving westward, starting with a velocity of $25 \mathrm{~m} / \mathrm{a}$. It reaches a maximum velocity in the middle portion, and again starts to reduce as we move towards the terminus (Figure 5a). As seen in Figure 5b, moving from an altitude of 600 to $200 \mathrm{~m}$, with a steep altitude change of $400 \mathrm{~m}$, the glacier reaches a maximum 
velocity. However, with a lower gradient of altitude change from 200 to $60 \mathrm{~m}$ near the terminus of the glacier, the velocity significantly reduces to $50 \mathrm{~m} / \mathrm{a}$. In the Rusanov Ice Cap, five glaciers were studied, which have velocities ranging from 11.49 to $21.93 \mathrm{~cm} /$ day. On the other hand, the Karpinsky Ice Cap has many small glaciers, with a more varied range of glacier velocities (Table 2). Eight glaciers were analyzed in this ice cap, which have surface velocities as low as $7.43 \mathrm{~cm} /$ day and as high as $32.12 \mathrm{~cm} / \mathrm{day}$. Most of the Karpinsky glaciers are found to be moving in a north-easterly or easterly direction, as observed in the LOS velocity map. As we go further south, the University Ice Cap (Glacier no.14) has a maximum surface velocity of $27.07 \mathrm{~cm} /$ day. For the Kropotkin Glacier (Zone IV in Figure 3a), flow rate is considerably low $(6.62 \mathrm{~cm} /$ day $)$.
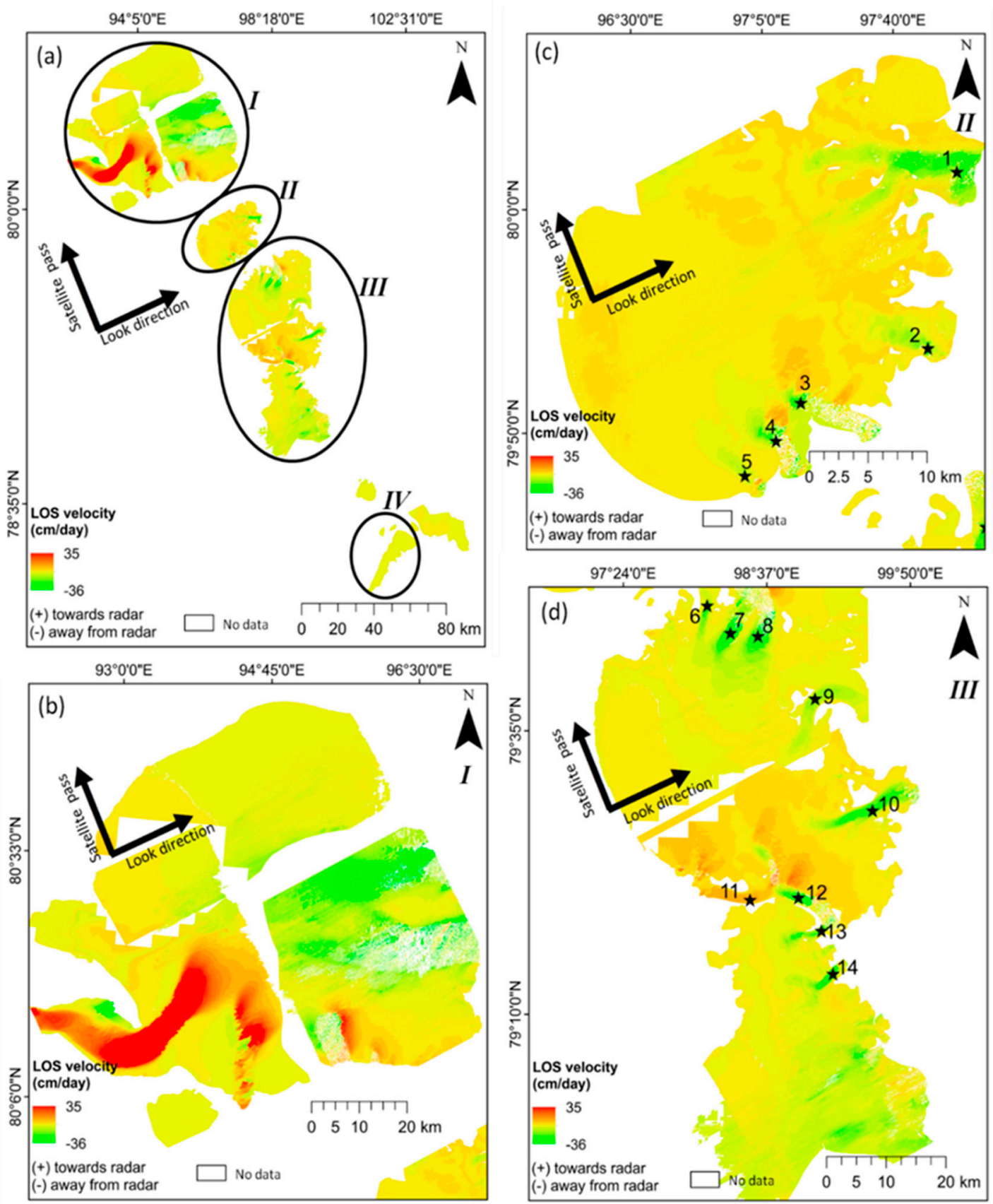

Figure 3. Glacier movement in LOS direction of the Severnaya Zemlya archipelago using the two-pass DInSAR technique. (a) An enlarged section of Severnaya Zemlya; (b) Academy of Sciences Ice Cap; (c) Rusanov Ice Cap; (d) Karpinsky and University ice caps (white portion represents no movement/no data). 


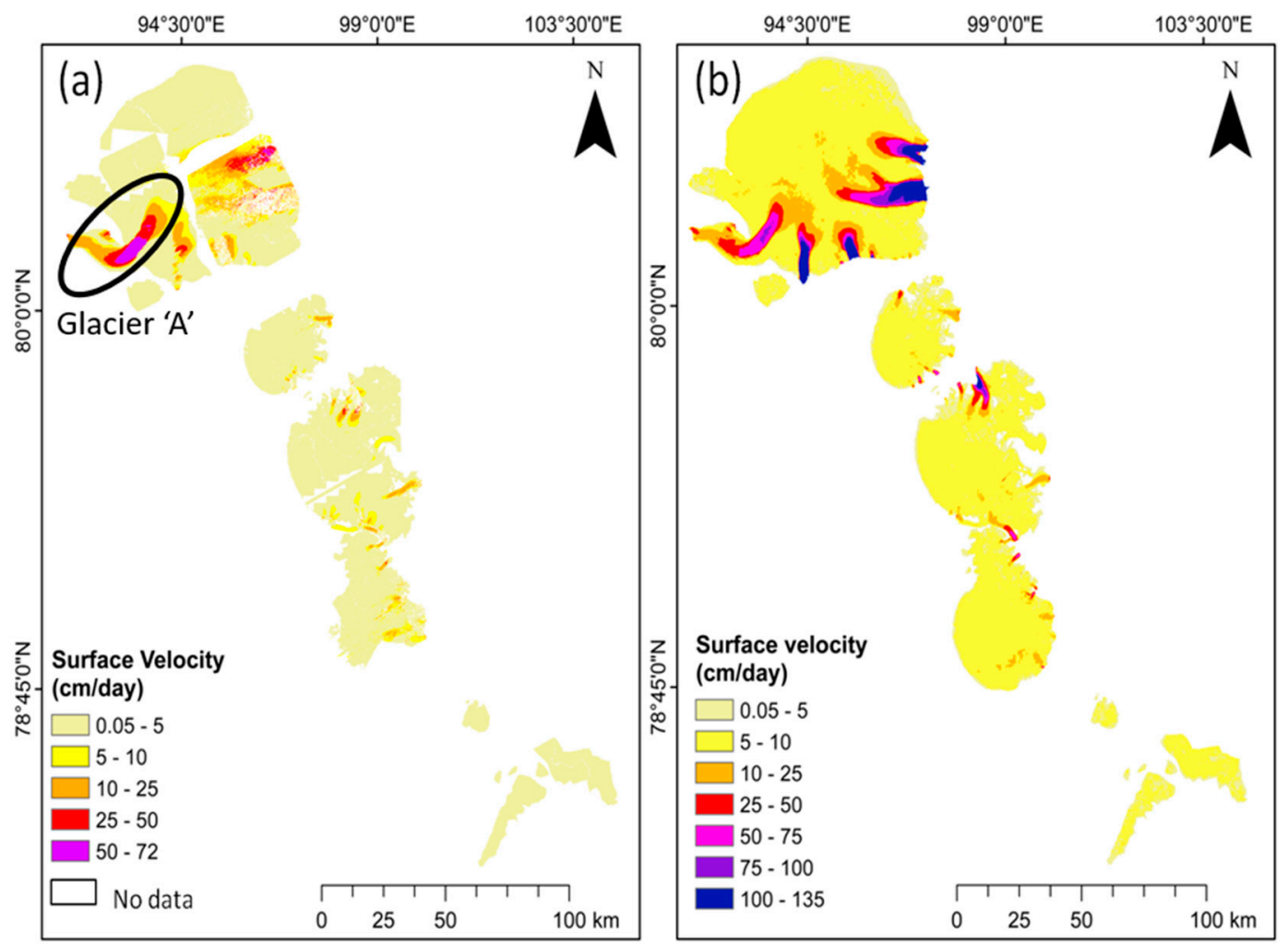

Figure 4. Glacier surface velocity (magnitude) of the Severnaya Zemlya archipelago using (a) two-pass DInSAR and (b) the pixel tracking (NASA ITS_LIVE product) technique.
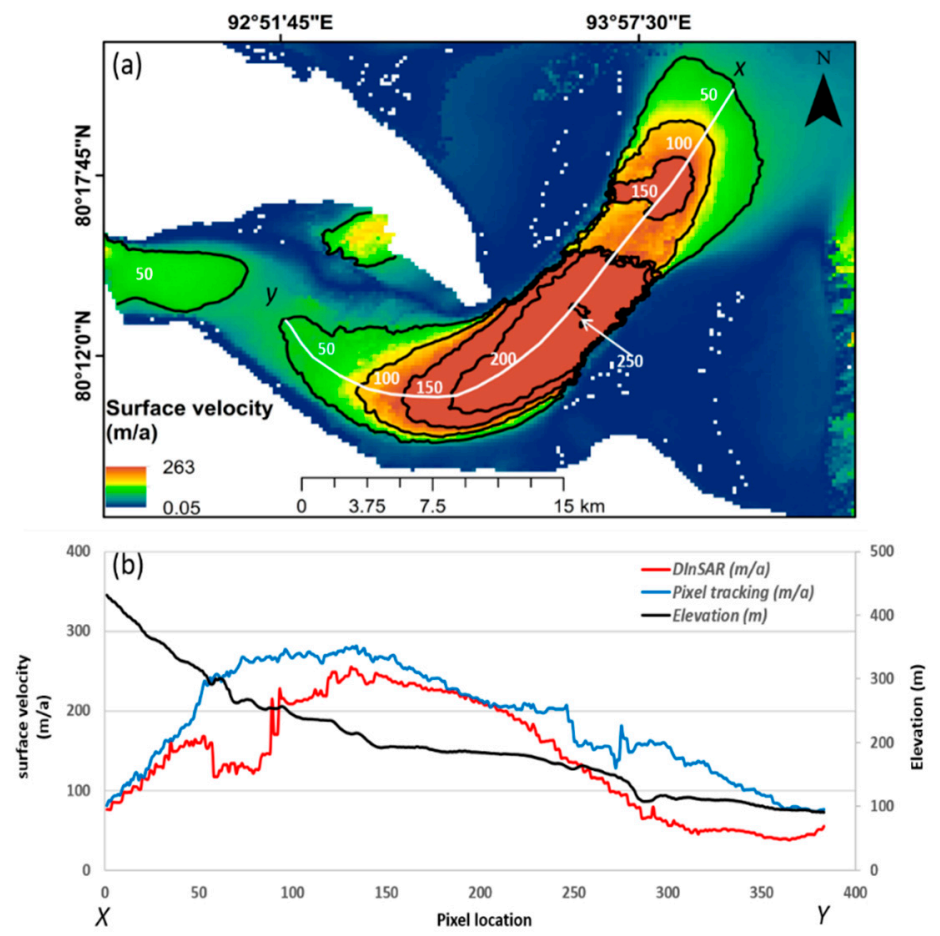

Figure 5. (a) Annual surface movement of an outlet glacier, ' $A$ ' (circled in Figure 4a), in the Academy of Sciences Ice Cap, shown with $50 \mathrm{~m} / \mathrm{a}$ difference contours. (b) Profile of velocity (m/a) in blue and red color for the pixel tracking and DInSAR methods, respectively, and elevation (m) shown in black color, along the flow line of a glacier from $X$ to $Y$, shown Figure 5 a. 
We also compared our DInSAR results with that obtained from the pixel tracking technique for the same area (see Figure 4), wherein the offset pixel tracking-based velocity was generated by the NASA MEaSUREs ITS_LIVE project [28,30]. In Figure 4, we show both DInSAR (Figure 4a) and offset-tracking-based (Figure $4 \mathrm{~b}$ ) velocity maps. The pixel tracking method shows higher velocity for the Academy of Sciences Ice Cap region compared to the DInSAR technique. However, for the Rusanov and University ice caps, there is no such clear trend observed. We compared both the DInSAR and pixel tracking techniques, along the glacier flow line for some selective glaciers (Figures 5 and 6), one from each ice cap ('A' from Academy of Sciences, ' 1 ' from Rusanov, '9' from Karpinsky, and '14' from University). For glacier 'A', both techniques show a similar trend. However, pixel tracking velocity is higher along the entire flow line. In fact, for glacier ' 9 ' in the Karpinsky Ice Cap, it saturates after point location 50. Further, the velocity extracted using th offset-tracking technique overestimates near the terminus. It must be noted that offset-tracking gives reasonable results for fast-moving glaciers. However, glacier ' 9 ' flows with low-velocity rates $(8.89 \mathrm{~cm} /$ day). For the remaining glaciers (glacier ' 1 ' and glacier ' 14 '), offset-tracking velocity is either overestimated for some regions or underestimated. This overestimating/underestimating may be due to the wrong pixel estimation (estimating offset for the neighboring pixel/subpixel) during the cross-correlation process.
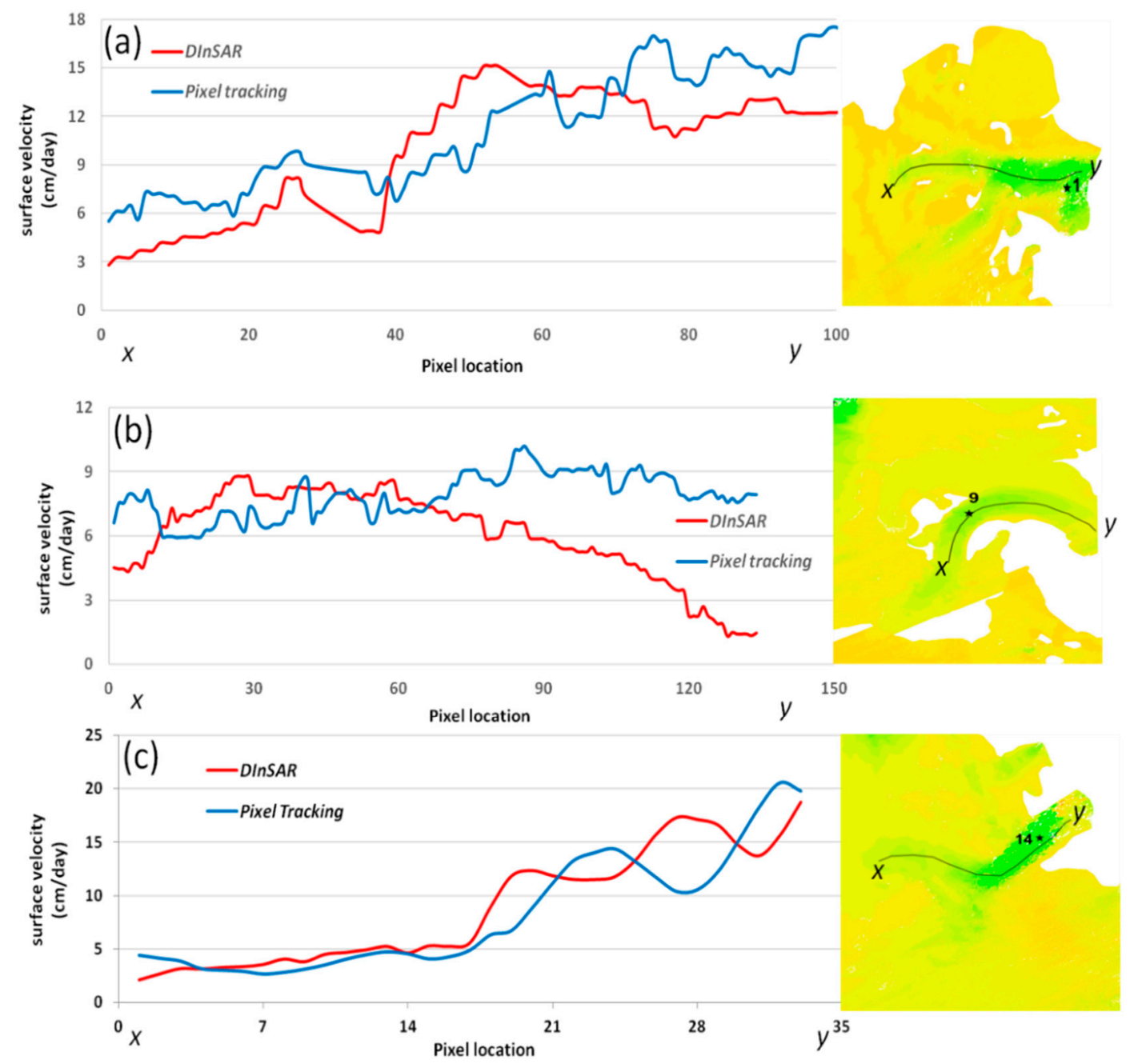

Figure 6. DInSAR-based velocity profile comparison with pixel tracking velocity map (Gardner et al. [28], ITS_LIVE) along the glacier flow line. (a) glacier ' 1 ' in the Rusanov Ice Cap, (b) glacier ' 9 ' in the Karpinsky Ice Cap, and (c) glacier '14' in the University Ice Cap. 
Table 2. Glaciers with observed maximum flow rates of the Rusanov, Karpinsky, and University ice caps shown in Figure 3c,d with star marks and listed below with their corresponding number.

\begin{tabular}{|c|c|c|c|c|}
\hline Glacier No & $\begin{array}{c}\text { Observed Max } \\
\text { Velocity (cm/day) }\end{array}$ & Ice Cap & Type of Glacier & Description \\
\hline 1 & 21.93 & Rusanov & Marine-terminating & $\begin{array}{l}\text { High at the terminus (increasing } \\
\text { gradually) }\end{array}$ \\
\hline 2 & 11.49 & Rusanov & Marine-terminating & $\begin{array}{l}\text { High at the terminus (increasing } \\
\text { gradually) }\end{array}$ \\
\hline 3 & 20.48 & Rusanov & Marine-terminating & $\begin{array}{l}\text { High velocity in the middle part } \\
\text { (frontal area has no data) }\end{array}$ \\
\hline 4 & 17.71 & Rusanov & Marine-terminating & $\begin{array}{l}\text { High velocity in the middle part } \\
\text { (frontal area has no data) }\end{array}$ \\
\hline 5 & 11.76 & Rusanov & Marine-terminating & $\begin{array}{c}\text { Near the terminus (velocity is almost } \\
\text { uniform) }\end{array}$ \\
\hline 6 & 19.12 & Karpinsky & Marine-terminating & $\begin{array}{l}\text { High velocity in the middle part } \\
\text { (low-high-low) }\end{array}$ \\
\hline 7 & 32.12 & Karpinsky & Marine-terminating & $\begin{array}{l}\text { High velocity in the middle part } \\
\text { (frontal area has no data) }\end{array}$ \\
\hline 8 & 26.19 & Karpinsky & Marine-terminating & $\begin{array}{l}\text { High velocity in the middle part } \\
\text { (frontal area has no data) }\end{array}$ \\
\hline 9 & 8.89 & Karpinsky & Marine-terminating & $\begin{array}{l}\text { High velocity in the middle part } \\
\text { (low-high-low) }\end{array}$ \\
\hline 10 & 17.80 & Karpinsky & Marine-terminating & High velocity in the middle part \\
\hline 11 & 7.43 & Karpinsky & Land-terminating & $\begin{array}{l}\text { High velocity in the middle part } \\
\text { (low-high-low) }\end{array}$ \\
\hline 12 & 25.48 & Karpinsky & Marine-terminating & $\begin{array}{l}\text { High velocity in the middle part } \\
\text { (frontal area has no data) }\end{array}$ \\
\hline 13 & 17.23 & Karpinsky & Marine-terminating & $\begin{array}{l}\text { High velocity at the terminus } \\
\text { (increasing gradually) }\end{array}$ \\
\hline 14 & 27.07 & University & Marine-terminating & $\begin{array}{l}\text { High velocity at the terminus } \\
\text { (increasing gradually) }\end{array}$ \\
\hline 15 & 6.62 & Kropotkin Glacier & Land-terminating & Constant flow \\
\hline 16 & 72.24 & Glacier 'A' & Marine-terminating & $\begin{array}{l}\text { High velocity in the middle part } \\
\text { (low-high-low) }\end{array}$ \\
\hline
\end{tabular}

Deformation error in LOS direction due to DEM error was estimated as mentioned in the methodology (Section 3.2). For the selected interferometry pair of ALOS-2/PALSAR-2, perpendicular baseline $\left(B_{\perp}\right)$ varies for the different pairs and ranges from 5.7 to $43.3 \mathrm{~m}$. Therefore, we estimated decorrelation error for all perpendicular baselines, and the corresponding readings are noted in Table 3 . $\theta_{1}$ is look angle: $28.2^{\circ}$ and, $R_{1}$ is slant range of ground point to the platform: $722 \mathrm{~km}$, and the DEM error value we considered as $12 \mathrm{~m}$.

Table 3. Deformation error in LOS direction due to the DEM error estimated for different perpendicular baselines corresponding to the 11 scene pairs (Numbers mentioned as shown in Figure 1).

\begin{tabular}{ccc}
\hline Scene Pair No. & Perpendicular Baseline $(\mathbf{m})$ & Deformation Error in LOS Direction $(\mathbf{c m})$ \\
\hline 1 & 33.2 & 0.12 \\
2 & 36.5 & 0.13 \\
3 & 39.6 & 0.14 \\
4 & 43.3 & 0.15 \\
5 & 15.1 & 0.05 \\
6 & 13.6 & 0.05 \\
7 & 12 & 0.04 \\
8 & 10.4 & 0.04 \\
9 & 8.8 & 0.03 \\
10 & 7.3 & 0.03 \\
11 & 5.7 & 0.02 \\
\hline
\end{tabular}

Apart from this, with the fact that there is no movement in ice-free areas, we estimated the mean displacement value for three ice-free regions (which directly gives the error). The observed error values 
(movement rate for three ice-free regions) are $0.53 \mathrm{~mm} /$ day, $1.49 \mathrm{~mm} /$ day, and $0.82 \mathrm{~mm} /$ day, and the average value of these regions $(0.09 \mathrm{~cm} /$ day $)$ was considered as the uncertainty.

\section{Discussion}

Amongst all ice caps, the Academy of Sciences Ice Cap has the maximum glacier velocity, $263 \mathrm{~m} / \mathrm{a}$, recorded for 2018. This value is 3.75 times higher than velocity rates reported for 1995 (70 m/a) by Dowdeswell et al. [27]. The technique used in both studies was DInSAR; however, Dowdeswell et al. [27] utilized the ERS Tandem pair acquired in September 1995 with a 1-day temporal gap. In the current study, the datasets used were ALOS-2/PALSAR-2, which were 14 days apart for April 2018. Recently, the same glacier was studied using Sentinel-1 by Sánchez-Gámez et al. [28] with a 12-day temporal gap between the SLC pairs of 2017. However, the method used was feature tracking, which is not as accurate as the DInSAR method for slow-moving ice, but for the fast-moving glacier like glacier ' $\mathrm{A}$ ', both feature tracking and DInSAR technique show a similar trend and pattern. Nonetheless, the trend in velocity was reflected with maximum flow rate at the center of the glacier and was used as a validation for a spike in velocity in this particular area. As seen from Figure $5 b$, there is a steep change in altitude in this region, as well as the bed topography, which might be the cause for such high velocity, increasing the glacier flow rate as high as three times in 23 years. To understand the processes that might be responsible for such local dynamic conditions, various factors could be possible, namely, slope, ice thickness, and sub-glacier bed topography. From previous studies, for ice caps, it has been observed that basal motion is a dominant component of surface motion [36], and this basal motion depends on the bed topography. It has been estimated that bed topography gradually increases from the top of the glacier (at $-100 \mathrm{~m}$ elevation) to the terminus of the glacier (at $-300 \mathrm{~m}$ elevation). The negative sign denotes that the glacier is below mean sea level. Around $50 \%$ of the glacier bed is below sea level, as reported by Dowdeswell and Williams [37].

Furthermore, it is interesting to note that the velocity of marine-terminating glaciers increases as it approaches the terminus. This observation is consistent with the results reported in Sánchez-Gámez et al. [28]. The basal movement could be due to deformable sub-glacial sediments and ice-sediment decoupling, along with continuous high sub-glacial water pressures [36]. As 50\% of the glacier is below sea level, and the glacier terminates into the nearby sea, there is a fair possibility that the bed topography consists of deformable marine sediments. Further, as there is an enhanced basal motion, there is a frictional heat dissipation which could even result in an increase in basal heat flux, providing the required energy to promote movement. The velocity pattern along the flow line is almost same as compared to the results shown in Dowdeswell et al. [27]. For marine-terminating glaciers, seawater helps accelerate the glacier velocity in the frontal part. However, here, we did not observe high flow rate at the frontal area as the datasets we selected were mostly confined to the accumulation season. For this study area, minimum velocity was observed in the accumulation seasons (March and April) and maximum in the ablation seasons (September and October). All other studied ice cap glaciers flow with low-velocity comparative to glaciers in the Academy of Sciences Ice Cap. Land-terminating glaciers (i.e., Kropotkin Glacier and glacier '11'in the Karpinsky Ice Cap) show very low movement rate.

While we compared our results (DInSAR-based) with the offset-tracking-based velocity measurements (NASA MEaSUREs ITS_LIVE), we observed that even though the trend was similar, there was either an overestimation or underestimation of velocity. This could be due to the error in offset pixel value estimation. Offset-tracking velocity maps were generated with Landsat- $4,-5,-7$, and -8 data. Further, the resolution at which these time-averaged velocities were provided was at $120 \mathrm{~m}$.

\section{Conclusions}

In this study, using the DInSAR method and ALOS-2/PALSAR-2 data, we estimated the glacier movement of the Severnaya Zemlya archipelago. We observed a high movement rate $(263 \mathrm{~m} / \mathrm{a})$ for one of the marine-terminating glaciers (glacier ' $A$ ') in the Academy of Sciences Ice Cap in the year 
2018. The velocity observed in this study shows a three-fold increase as compared to the velocity $(70 \mathrm{~m} / \mathrm{a})$ reported in 1995. Climatic parameters shall not dictate such regional changes but the intrinsic properties of the ice cap itself might. The plausible reason has been identified as the presence of an inefficient sub-glacial hydraulic system which leads to a sudden increase in velocity. The existence of such a system is supported by the fact that a large portion of such glaciers is submerged in the sea and deformable sediments are common. This leads to the development of low pressure conditions and fast basal movement, which is reflected at the surface. Owing to such high-velocity changes over the past 23 years, it is important that a time series analysis of glacier velocity be done for a better understanding of the glacier/ice cap dynamics and the effect of climatic changes. For other glaciers in this archipelago, namely, in the Karpinsky Ice Cap, for land-terminating glaciers, we observed a comparatively low movement rate with respect to the marine-terminating glaciers. Such information about the ice caps adds to the existing sparse database for the glacier movement in the Severnaya Zemlya archipelago, which could act as a useful input for modeling future glacier velocity.

Author Contributions: Conceptualization, G.S.; data curation, B.R.N., T.E.K.; formal analysis, B.R.N. and D.B.; funding acquisition, G.S., A.F.G., I.I.L., T.E.K., and J.A.-N.; investigation, A.F.G. and I.I.L.; methodology, B.R.N.; supervision, G.S.; visualization, B.R.N., D.B., G.S., and J.A.-N.; writing-original draft, B.R.N. and D.B.; writing—review and editing, G.S., A.F.G., I.I.L., T.E.K., and J.A.-N.

Funding: Financial supports were received under the BRICS Science, Technology and Innovation Framework Programme (BRICS STI FP) for project 'Col-GaSS' from the Department of Science and Technology, India (project no. DST/IMRCD/BRICS/PilotCall1/Col-GaSS/2017 (G)), the Russian Foundation for Basic Research, Russia (Project no. 17-55-80107), and the Brazilian National Council for Scientific and Technological Development, Brazil (project number 441810/2016-0).

Acknowledgments: The authors would like to thank JAXA for providing the ALOS-2/PALSAR-2and ALOS datasets under the project JAXA-P3056. Velocity maps were generated using SARPROZ software, and the authors appreciate the SARPROZ team for giving the evaluation version. The authors would also like to thank the United States National Aeronautics and Space Administration (NASA) and the Ministry of Economy, Trade, and Industry (METI) of Japan for providing ASTER DEM.

Conflicts of Interest: The authors declare no conflict of interest.

\section{References}

1. IPCC. Climate Change: The physical Science Basis. Contribution of Working Group I to the Fourth Assessment Report of the Intergovernmental Panel on Climate Change; Cambridge University Press: Cambridge, UK; New York, NY, USA, 2007.

2. Scherler, D.; Bookhagen, B.; Strecker, M.R. Spatially variable response of Himalayan glaciers to climate change affected by debris cover. Nat. Geosci. 2011, 4, 156-159. [CrossRef]

3. Kumar, P.; Shukla, A.; Kamal, R.; Singh, A. Assessing the status of glaciers in part of the Chandra basin, Himachal Himalaya: A multiparametric approach. Geomorphology 2017, 284, 99-114.

4. Space Applications centre. Monitoring Snow and Glaciers of the Himalayas; Space Applications centre: Ahmedabad, India, 2016.

5. Bhutiyani, M.R.; Kale, V.S.; Pawar, N.J. Climate change and the precipitation variations in the northwestern Himalaya: 1866-2006. Int. J. Climatol. 2010, 30, 535-548. [CrossRef]

6. Burgess, E.W.; Forster, R.R.; Larsen, C.F. Flow velocities of Alaskan glaciers. Nat. Commun. 2013, 4, 1-8. [CrossRef]

7. Liu, L.; Jing, Z.; Zhang, X. The application of GPS in glacier flow velocity: A case study of Qiyi Glacier. Appl. Mech. Mater. 2012, 130, 1794-1798. [CrossRef]

8. Strozzi, T.; Luckman, A.; Murray, T.; Wegmüller, U.; Werner, C.L. Glacier Motion Estimation Using SAR Offset-Tracking Procedures. IEEE Trans. Geosci. Remote Sens. 2002, 40, 2384-2391. [CrossRef]

9. Satyabala, S.P. Spatiotemporal variations in surface velocity of the Gangotri glacier, Garhwal Himalaya, India: Study using synthetic aperture radar data. Remote Sens. Environ. 2016, 181, 151-161. [CrossRef]

10. Goldstein, R.M.; Engelhardt, H.; Kamb, B.; Frolich, R.M. Satellite radar interferometry for monitoring ice sheet motion: Application to an Antarctic ice stream. Science 1993, 262, 1525-1530. [CrossRef] 
11. Joughin, I.R.; Winebrenner, D.P. Observations of ice-sheet motion in Greenland using satellite. Geophys. Res. Lett. 1995, 22, 571-574. [CrossRef]

12. Cheng, X.; Li, X.W.; Shao, Y.; Li, Z. DInAR measurement of glacier motion in Antarctic Grove Mountain. Chin. Sci. Bull. 2007, 52, 358-366. [CrossRef]

13. Moll, A.; Braun, M.; Lluberas, A. Determination of Glacier Velocities on King George Island (Antarctica) by DInSAR; IGARSS: Denver, CO, USA, 2006; pp. 1236-1239.

14. Wangensteen, B.; Weydahl, D.A.N.J.; Hagen, J.O.N.O.V.E. Mapping glacier velocities on Svalbard using ERS tandem DInSAR data Mapping glacier velocities on Svalbard using ERS tandem DInSAR data. Nor. Geogr. Tidsskr-Nor. J. Geogr. 2005, 59, 276-285. [CrossRef]

15. Caló, F.; Notti, D.; Galve, J.P.; Abdikan, S.; Görüm, T.; Pepe, A.; Şanli, F.B. DInSAR-based detection of land subsidence and correlation with groundwater depletion in Konya plain, Turkey. Remote Sens. 2017, 9, 83. [CrossRef]

16. Tomás, R.; Herrera, G.; Delgado, J.; Lopez-Sanchez, J.M.; Mallorquí, J.J.; Mulas, J. A ground subsidence study based on DInSAR data: Calibration of soil parameters and subsidence prediction in Murcia City (Spain). Eng. Geol. 2010, 111, 19-30. [CrossRef]

17. Fang, J.; Xu, C.; Wen, Y.; Wang, S.; Xu, G.; Zhao, Y.; Yi, L. The 2018 Mw 7.5 Palu earthquake: A supershear rupture event constrained by InSAR and broadband regional seismograms. Remote Sens. 2019, 11, 1330. [CrossRef]

18. Mora, O.; Ordoqui, P.; Iglesias, R.; Blanco, P. Earthquake Rapid Mapping Using Ascending and Descending Sentinel-1 TOPSAR Interferograms. Procedia Comput. Sci. 2016, 100, 1135-1140. [CrossRef]

19. Zebker, H.A.; Rosen, P.A.; Goldstein, R.M.; Gabriel, A.; Werner, C.L. On the derivation of coseismic displacement fields using differential radar interferometry: The Landers earthquake. J. Geophys. Res. 1994, 99, 617-634. [CrossRef]

20. Lu, Z.; Freymueller, J.T. Synthetic aperture radar interferometry coherence analysis over Katmai volcano group, Alaska. J. Geophys. Res. Solid Earth 1998, 103, 29887-29894. [CrossRef]

21. Chaussard, E.; Amelung, F.; Aoki, Y. Characterization of open and closed volcanic systems in Indonesia and Mexico using InSAR time series. J. Geophys. Res. Solid Earth 2013, 118, 3957-3969. [CrossRef]

22. Massonnet, D.; Rossi, M.; Carmona, C.; Adragna, F.; Peltzer, G.; Feigl, K.; Rabaute, T. The displacement field of the Landers earthquake mapped By Radar Interferometry. Nature 1993, 364, 138-142. [CrossRef]

23. Kumar, V.; Venkataraman, G.; Larsen, Y. IGARSS. In Proceedings of the SAR Interferometry and offset tracking approaches for glacier movement estimation in the Himalaya, Vancouver, BC, Canada, 24-29 July 2011; pp. 3175-3178.

24. Sánchez-gámez, P.; Navarro, F.J. Glacier Surface Velocity Retrieval Using D-InSAR and Offset Tracking Techniques Applied to Ascending and Descending Passes of Sentinel-1 Data for Southern Ellesmere Ice Caps, Canadian Arctic. Remote Sens. 2017, 9, 442. [CrossRef]

25. Wang, T.; Jónsson, S. Improved SAR amplitude image offset measurements for deriving three-dimensional coseismic displacements. IEEE J. Sel. Top. Appl. Earth Obs. Remote Sens. 2015, 8, 3271-3278. [CrossRef]

26. Ou, D.; Tan, K.; Du, Q.; Chen, Y.; Ding, J. Decision fusion of D-InSAR and pixel offset tracking for coal mining deformation monitoring. Remote Sens. 2018, 10, 1055. [CrossRef]

27. Dowdeswell, J.A.; Bassford, R.P.; Gorman, M.R.; Williams, M.; Glazovsky, A.F.; Macheret, Y.Y.; Shepherd, A.P.; Vasilenko, Y.V.; Savatyuguin, L.M.; Hubberten, H.W.; et al. Form and flow of the Academy of Sciences Ice Cap, Severnaya Zemlya, Russian High Arctic. J. Geophys. Res. 2002, 107, EPM-5. [CrossRef]

28. Sánchez-Gámez, P.; Navarro, F.J.; Glazovsky, A.F.; Bassford, R.P.; Dowdeswell, J.A. Intra- and inter-annual variability in dynamic discharge from the Academy of Sciences Ice Cap, Severnaya Zemlya, Russian Arctic, and its role in modulating mass balance. J. Glaciol. 2019, 65, 780-797. [CrossRef]

29. Willis, M.J.; Zheng, W.; Durkin, W.J., IV; Pritchard, M.E.; Ramage, J.M.; Dowdeswell, J.A.; Benham, T.J.; Bassford, R.P.; Stearns, L.A.; Glazovsky, A.F.; et al. Massive destabilization of an Arctic ice cap. Earth Planet. Sci. Lett. 2018, 502, 146-155. [CrossRef]

30. Gardner, A.S.; Fahnestock, M.A.; Scambos, T.A. Sept,2019:ITS_LIVE Regional Glacier and Ice Sheet Surface Velocities; Data archived at National Snow and Ice Data Center: Pasadena, CA, USA, 2019.

31. Raju, N.B.; Singh, G.; Anil, V.K.; Kapil, M. Optimum Conditions for Differential Sar Interferometry Technique to Estimate Himalayan Glacier Velocity. In Proceedings of the ISPRS Ann. Photogramm. Remote Sens. Spatial Inf. Sci., Dehradun, India, 20-23 November 2018; Volume IV-5, pp. 137-140. 
32. Gardner, A.S.; Moholdt, G.; Scambos, T.; Fahnstock, M.; Ligtenberg, S.; Broeke, M. Van Den Increased West Antarctic and unchanged East Antarctic ice discharge over the last 7 years. Cryosphere 2018, 12, 521-547. [CrossRef]

33. Strozzi, T.; Paul, F.; Wiesmann, A.; Schellenberger, T.; Kääb, A. Circum-arctic changes in the flow of glaciers and ice caps from satellite SAR data between the 1990s and 2017. Remote Sens. 2017, 9, 947. [CrossRef]

34. Michael, A.; Robert, C. ASTER Global Digital Elevation Model V003; NASA EOSDIS Land Processes DAAC; NASA/METI/AIST/Japan Spacesystems, and U.S./Japan ASTER Science Team: Pasadena, CA, USA, 2018.

35. Tao, Q.; Gao, T.; Liu, G.; Wang, Z. Effect of external digital elevation model on monitoring of mine subsidence by two-pass differential interferometric synthetic aperture radar. J. Appl. Remote Sens. 2017, 11, 026037. [CrossRef]

36. Doyle, S.H.; Hubbard, B.; Christoffersen, P.; Young, T.J.; Hofstede, C.; Bougamont, M.; Box, J.E.; Hubbard, A. Physical Conditions of Fast Glacier Flow: 1. Measurements From Boreholes Drilled to the Bed of Store Glacier, West Greenland. J. Geophys. Res. Earth Surf. Res. 2018, 123, 324-348. [CrossRef]

37. Dowdeswell, J.A.; Williams, M. Surge-type glaciers in the Russian High Arctic identified from digital satellite imagery. J. Glaciol. 1997, 43, 489-494. [CrossRef]

(C) 2019 by the authors. Licensee MDPI, Basel, Switzerland. This article is an open access article distributed under the terms and conditions of the Creative Commons Attribution (CC BY) license (http://creativecommons.org/licenses/by/4.0/). 